\title{
Potensi Penyalahgunaan Wewenang Organisasi Kemasyarakatan (ORMAS) Fiktif Dalam Masyarakat Indonesia
}

\author{
Sandryones Palinggi ${ }^{1}$, Putri M. Prayogyandarini ${ }^{2}$ \\ ${ }^{1}$ Institut Sains dan Teknologi Nasional \\ ${ }^{2}$ Universitas Islam Negeri Syarif Hidayatullah Jakarta \\ Email: sandryones@gmail.com
}

Naskah diterima 24 Maret 2020, Revisi 30 Maret 2020, Terbit 19 April 2020

\begin{abstract}
Abstrak
DOI: doi.org/10.21107/pamator.v13i1.6936

Fenomena yang terjadi dalam masyarakat Indonesia tentang adanya organisasi kemasyarakatan dapat diterima sebagai bentuk dari keinginan masyarakat untuk berkarya. Undang-Undang Dasar 1945 pada Pasal 28, turut mendukung hal tersebut dimana negara menjamin kemerdekaan berserikat, berkumpul, dan mengeluarkan pendapat baik lisan dan tulisan kepada setiap warga negara. Organisasi kemasyarakatan pada umumnya diartikan sebagai wadah perkumpulan untuk menciptakan sebuah kegiatan yang bersifat positif serta memiliki visi misi yang bertujuan demi kemajuan bersama. Kemunculan organisasi kemasyarakatan fiktif yang bercirikan kerajaan telah merusak hegemoni dan cita-cita luhur dari kemerdekaan berserikat. Potensi yang ditimbulkan telah mengarah pada bentuk kriminal yang berdampak pada masyarakat kecil. Metode penelitian yang digunakan dalam penelitian ini adalah analisis deskriptif dengan metode pendekatan kualitatif dimana ditujukan untuk mengumpulkan informasi secara aktual dan terperinci, mengidentifikasi masalah, menentukan apa yang dilakukan orang lain dalam menghadapi masalah yang sama di waktu mendatang. Tujuan dari penelitian ini adalah memberikan analisis secara deskriptif tentang organisasi kemasyarakatan yang bersifat fiktif serta potensi penyalahgunaan wewenang organisasi dalam masyarakat. Adapun kesimpulan dari penelitian ini adalah masyarakat mampu lebih jeli dalam menentukan jenis organisasi kemasyarakatan yang akan diikuti agar tidak menjadi objek dari kasus penipuan yang mengatasnamakan organisasi kemasyarakatan.
\end{abstract}

Kata Kunci : organisasi kemasyarakatan, fiktif, kriminalisasi, potensi kejahatan.

\begin{abstract}
The phenomenon that occurs in Indonesian society about the existence of social organizations can be accepted as a form of community desire to work. The 1945 Constitution in Article 28, also supports this matter in which the state guarantees freedom of association, assembly, and issuing both oral and written opinions to every citizen. Social organizations are generally defined as a forum for associations to create a positive activity and have a vision and mission that aims for mutual progress. The emergence of fictitious social organizations characterized by empires has damaged the hegemony and noble ideals of freedom of association. The potential that has arisen has led to a criminal form that impacts small communities. The research method used in this research is descriptive analysis with a qualitative approach which is aimed at gathering actual and detailed information, identifying problems, determining what other people are doing in dealing with similar problems in the future. The purpose of this study is to provide a descriptive analysis of fictitious community organizations and the potential abuse of organizational authority in society. The conclusion of this research is that the community is able to be more observant in determining the type of social organization that will be followed so as not to be the object of a fraud case in the name of a social organization.
\end{abstract}

Keywords : social organizations, fictive organizations, criminalization, crime potential.

\section{PENDAHULUAN}

Sejak Era Reformasi digulirkan pada tahun 1998, Indonesia telah memasuki babak baru dalam sistem ketatanegaraan dan sistem kemasyarakatan. Banyaknya perkumpulan yang mengatasnamakan organisasi telah banyak ditemui hingga sekarang, baik yang bersifat politis, keagamaan hingga yang bersifat sosial seperti ormas.

Masing-masing organisasi memiliki ciri tersendiri dalam menjalankan roda 
kegiatan. Menurut Undang-Undang Dasar 1945 pada Pasal 28, turut mendukung hal tersebut dimana negara menjamin kemerdekaan berserikat, berkumpul, dan mengeluarkan pendapat baik lisan dan tulisan kepada setiap warga negara.

Kehadiran organisasi bersifat kemasyarakatan, tidak dapat disangkal, telah banyak memberikan dampak yang sangat besar dalam perjalanan menuju kemerdekaan. Organisasi Boedi Oetomo yang didirikan pada tanggal 20 Mei 1908 menandai kemunculan para cendikiawan muda pada zaman tersebut. Namun tidak jarang pula, beberapa organisasi juga memberikan dampak yang sangat merugikan bagi masyarakat Indonesia. (Marwenny, Fauzi, \& Cenery, 2018)

Kemunculan organisasi kemasyarakatan yang bercirikan kerajaan pada awal tahun 2020, yang dinamakan Keraton Agung Sejagat (KAS), menjadi salah satu bentuk organisasi kemasyarakatan yang menimbulkan keresahan, tidak hanya bagi masyarakat di sekitar tempat tersebut, tetapi hampir di seluruh masyarakat Indonesia pada umumnya (Dzulfaroh \& Nugroho, 2020). Jika menilik dari legalitas hukum terhadap organisasi ini, dapat dikatakan bahwa Keraton Agung Sejagat tidak memiliki dasar hukum pembentukan organisasi kemasyarakatan sehingga dapat dikatakan bahwa organisasi ini merupakan organisasi yang bersifat fiktif (Farasonalia \& Arief, 2020).

Kehadiran organisasi kemasyarakatan seperti Keraton Agung Sejagat, justru mendapatkan perhatian yang cukup besar di lingkungan tempat didirikannya organisasi tersebut. Tidak sedikit dari mereka sebenarnya mengetahui bahwa organisasi semacam itu tidak memiliki legalitas hukum yang jelas, namun tetap memilih diam dan mengikuti kegiatan yang dilaksanakan oleh Keraton Agung Sejagat.

Tujuan penulis dalam penelitian ini adalah memberikan analisis secara deskriptif tentang organisasi kemasyarakatan yang bersifat fiktif serta potensi penyalahgunaan wewenang organisasi dalam masyarakat. Diharapkan dengan adanya penelitian ini, mampu meminimalisir keterlibatan masyarakat dalam kegiatan yang dilaksanakan oleh organisasi kemasyarakatan sejenis sehingga dampak yang ditimbulkan menjadi minimal.

Dalam penelitian yang berjudul Potensi Penyalahgunaan Wewenang Organisasi Kemasyarakatan (Ormas) Fiktif dalam Masyarakat Indonesia, dapat memberikan gambaran kepada masyarakat Indonesia tentang dampak yang ditimbulkan dengan kehadiran organisasi tersebut dalam lingkup masyarakat, khususnya di masyarakat Indonesia.

\section{METODOLOGI}

Metode penelitian yang digunakan dalam penelitian ini adalah analisis deskriptif dengan metode pendekatan kualitatif. Adapun metode penelitian tersebut ditujukan untuk mengumpulkan informasi secara aktual dan terperinci, mengidentifikasi masalah, membuat perbandingan atau evaluasi, serta menentukan apa yang dilakukan orang lain dalam menghadapi masalah yang sama dan belajar dari pengalaman mereka dalam menetapkan rencana dan keputusan di waktu mendatang.

Dengan demikian, penelitian deskriptif dengan pendekatan kualitatif hanya menguraikan tanggapan terhadap sebuah situasi, peristiwa, maupun fenomena yang terjadi sehingga tidak diperlukan penjelasan antara hubungan kausalitas maupun uji hipotesis.

Dalam Buku dengan berjudul Penelitian Kualitatif: Komunikasi, Ekonomi, Kebijakan Publik, dan IImu Sosial Lainnya (Bungin, 2011), metode literatur adalah salah satu metode pengumpulan data yang digunakan dalam metode penelitian sosial untuk melacak data catatan peristiwa. Selanjutnya, literatur yang digunakan oleh penulis untuk mengumpulkan data termasuk sumbersumber dari penelitian sebelumnya, seperti jurnal, buku referensi, observasi dan dokumentasi online yang terkait pengembangan dari dampak yang terjadi dalam masyarakat terkait organisasi kemasyarakatan.

\section{HASIL PEMBAHASAN}

Organisasi Kemasyarakatan Fiktif dalam Masyarakat Indonesia

Organisasi kemasyarakatan pada umumnya diartikan sebagai wadah perkumpulan untuk menciptakan sebuah 
kegiatan yang bersifat positif serta memiliki visi misi yang bertujuan demi kemajuan bersama. Menurut jurnal yang berjudul Analisis Penanganan Konflik Antar Organisasi Kemasyarakatan di Sumatera Utara (Medan) dan Jawa Tengah (Surakarta), disebutkan bahwa organisasi masyarakat adalah perkumpulan sosial yang dibentuk oleh masyarakat, baik yang berbadan hukum maupun yang tidak berbadan hukum secara sukarela atas dasar kesamaan kegiatan, profesi, tujuan yang berfungsi sebagai sarana partisipasi masyarakat dalam pembangunan bangsa dan negara. Sebagai makhluk yang selalu hidup bersama-sama, manusia membentuk organisasi sosial untuk mencapai tujuantujuan tertentu yang tidak dapat mereka capai sendiri (Zainuddin, 2016).

Fenomena kehadiran organisasi kemasyarakatan fiktif bercirikan kerajaan, telah ada pada saat era Presiden Soekarno. Dicatat dalam Harian Het Parool edisi 19 Juli 1958 bahwa pada 8 Agustus 1957 di Palembang, seperti diceritakan Het Parool, muncul seorang laki-laki berusia 42 yang datang dari pedalaman Sumatera. Dia mengaku sebagai pangeran dari wilayah yang dulunya dianggap wilayah kekuasaan Sriwijaya. Namanya Idrus Bin Pohon. Dia punya lima orang abdi. Di Palembang, dia dan kelompoknya berpenampilan ala sipil dan militer (Matanasi, 2018).

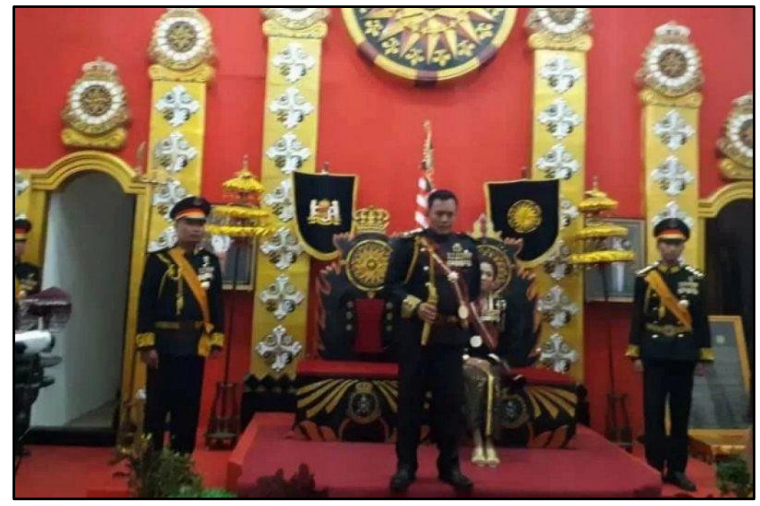

Gambar 1. Organisasi Kemasyarakatan Keraton Agung Sejagat

(Sumber : Pikiran Rakyat, 2020)

Kemunculan kerajaan fiktif lainnya yang menggemparkan masyarakat Indonesia pada awal 2020, adalah Keraton Agung Sejagat. Kerajaan ini mengklaim memiliki pengikut sebanyak 450 orang dan Sebagian besar berasal dari Yogyakarta. Kerajaan yang berdiri di Kabupaten Purworejo (Jawa Tengah), menyatakan bahwa Keraton Agung Sejagat merupakan kerajaan atau kekaisaran dunia yang muncul karena telah berakhir "perjanjian 500 tahun" yang lalu, terhitung sejak hilangnya Kemaharajaan Nusantara, yaitu imperium Majapahit pada 1518 sampai 2018 (Anugrahadi, 2020).

Adapula sebuah organisasi kemasyarakatan bercirikan kerajaan berdiri di Kota Tangerang bernama King of The King. Kerajaan ini mengklaim bahwa King of The King menduduki dua lembaga keuangan tertinggi di dunia. Pertama yaitu Union Bank Switzerland (UBS) dan Indonesia Mercusuar Dunia (IMD). Selain itu, memiliki kekayaan Rp 60.000 triliun. Kerajaan ini menyatakan bahwa akan membantu Indonesia melunasi utang luar negeri, menyejahterakan rakyat Indonesia melalui kekayaan yang dimiliki oleh kerajaan, serta membeli peralatan militer Indonesia untuk sistem pertahanan (Wiryono \& Carina, 2020).

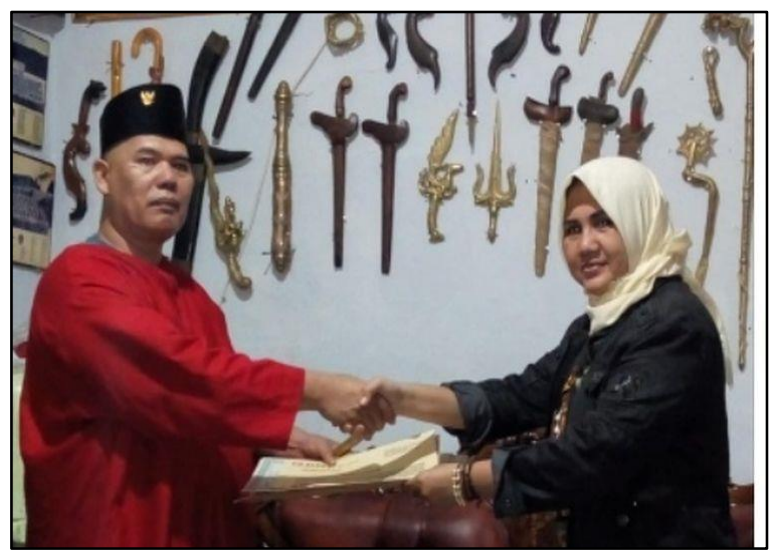

Gambar 2. Organisasi Kemasyarakatan King of The King

(Sumber : Kompas, 2020)

Organisasi kemasyarakatan bercirikan kerajaan yang sangat fenomenal berdiri di Kota Bandung (Jawa Barat) bernama Sunda Empire. Kerajaan ini mengklaim mampu mengendalikan nuklir dunia, dan merupakan pewaris harta benda bumi. Kerajaan yang menyebut diri mereka sebagai Kekaisaran matahari, melakukan aktivitas sejak 2017 serta memilki simpatisan sekitar 1.000 orang yang tersebar di seluruh Jawa Barat hingga Aceh (Bunga \& Sugiharto, 2020). Sunda Empire yang bermarkas di Bandung itu juga mengaku sebagai lembaga tingkat dunia yang memiliki tujuan untuk menyejahterakan dan mewujudkan perdamaian dunia. Sunda 
Empire beranggotakan negara dan pemerintahan di dunia dan terdiri atas enam wilayah, di antaranya, Bandung sebagai titik nol, Sunda Nusantara, Sunda Archipelago, Sunda Eropa, Sunda Pasific, dan Sunda Mainland (Ucu, 2020).

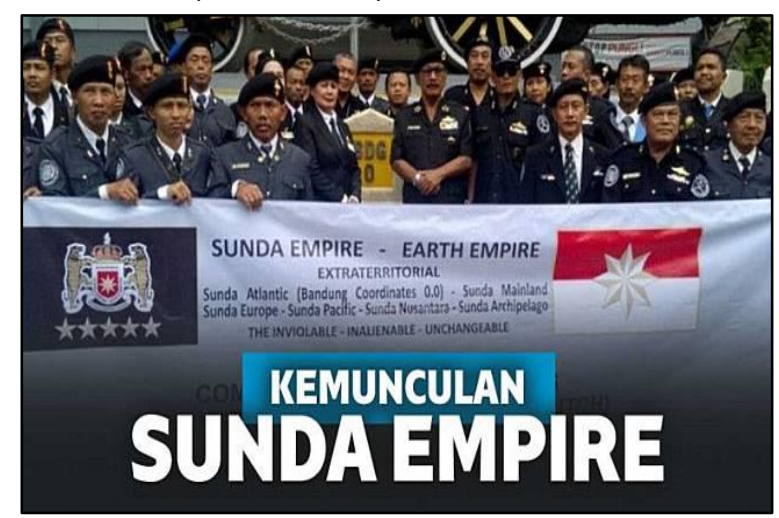

Gambar 3. Organisasi Kemasyarakatan Sunda Empire

(Sumber : Line Today, 2020)

Berbeda halnya dengan sebuah organisasi kemasyarakatan yang berdiri di Kabupaten Kutai Kartanegara (Kalimantan Timur), bernama Kutai Mulawarman. Kerajaan ini mengklaim bahwa mereka merupakan organisasi kemasyarakatan yang memiliki dasar hukum yang jelas. Hal ini dibuktikan melalui SK dari Kemenkumham nomor AHU0067708.AH.01.07 Tahun 2016. Walau demikian penggunaan nama kerajaan menjadi Kutai Mulawarman, tidak mendasar dikarenakan nama sesungguhnya dari organisasi kemasyarakatan ini adalah Perkumpulan Kerajaan Kutai Mulawarman (Oktavian, 2020).

\section{Penyalahgunaan Wewenang Organisasi Kemasyarakatan}

Dalam banyak kasus yang terjadi dalam masyarakat yang diakibatkan oleh kemunculan organisasi kemasyarakatan fiktif, kasus penipuan merupakan kasus yang paling sering didapati. Penipuan adalah sebuah tindakan seseorang atau sekelompok orang membuat kesan bahwa sesuatu itu benar dan tidak palsu untuk membuat orang lain memberikan kepercayaan. Secara formal, penipuan didefinisikan sebagai tindakan membujuk orang lain dengan tipu muslihat, rangkaian kata-kata bohong, nama palsu, keadaan palsu agar memberikan sesuatu (Rusmana, 2015).

Para petinggi dari organisasi kemasyarakatan fiktif, menggunakan pengaruhnya untuk mengelabui para pengikutnya dengan sebuah iming-iming jabatan/kedudukan, upah/gaji, maupun fasilitas penunjang. Dalam interaksi tatap muka (face to face interactions) maupun melalui media (mediated interaction) terdapat pelaku yang menyatakan atau menawarkan sesuatu atau mengajak berbuat sesuatu yang disampaikan dalam bentuk lambing yang maknanya disepakati oleh semua pihak yang berinteraksi sehingga dapat menciptakan pemahaman yang sama tentang hal yang dipertukarkan dalam interaksi (Rusmana, 2015).

Untuk meningkatkan pengaruh dari organisasi fiktif tersebut, para petinggi organisasi tidak segan untuk meyebarkan berita bohong terkait organisasi yang dipimpinnya. Berita bohong yang disebarkan tersebut memiliki tujuan agar jumlah pengikut dari organisasi tersebut terus bertambah, yang menyebabkan kasus penipuan dalam organisasi itupun meningkat. Hal ini dilakukan agar roda kegiatan yang diselenggarakan oleh organisasi tersebut dibiayai oleh para pengikutnya.

Dalam jurnal berjudul The Descriptive Analysis of Hoax Spread Through Social Media in Indonesia Media Perspective (Klau Lekik, Palinggi, \& Ranteallo, 2019), disebutkan bahwa faktor yang membuat tipuan begitu viral adalah kurangnya kepastian hukum yang mengatur masalah tersebut. Padahal, aturan hukum selalu terlambat untuk membatasi pergerakan pembuat tipuan atau penyebar. Kurangnya literasi pengguna media sosial. Pengguna harus memprioritaskan komunikasi dua arah di media sosial. Jadi, tipuan yang tersebar itu dapat dilawan dengan membalas informasi yang sebenarnya. Provokasi terhadap publik tentang berita palsu sangat menakutkan dan memiliki efek jangka panjang. Penyebarannya tidak bisa dihilangkan tetapi bisa dikurangi sebagai upaya untuk memberantas berita palsu.

Dalam kasus penipuan yang dilakukan oleh Idrus dan Makonah tahun 1957, diketahui bahwa keduanya menggunakan ketenaran mereka untuk mendapatkan 
fasilitas negara. Dan akhirnya mendapatkan jerat hukuman selama 9 bulan penjara dengan tuduhan penipuan (Matanasi, 2018).

Kasus Keraton Agung Sejagat pun demikian. Dalam pengakuan yang dibuat oleh pimpinan Keraton Agung Sejagat, diketahui bahwa Kerajaan yang mereka buat adalah sebuah fiktif belaka. Kedua pemimpin Kerajaan tersebut terancam hukuman 10 tahun penjara dengan tuduhan terkait penipuan seperti yang tertera pada Pasal 14 UU RI No.1 Tahun 1946 tentang peraturan hukum pidana terkait penipuan (Prabawati, 2020).

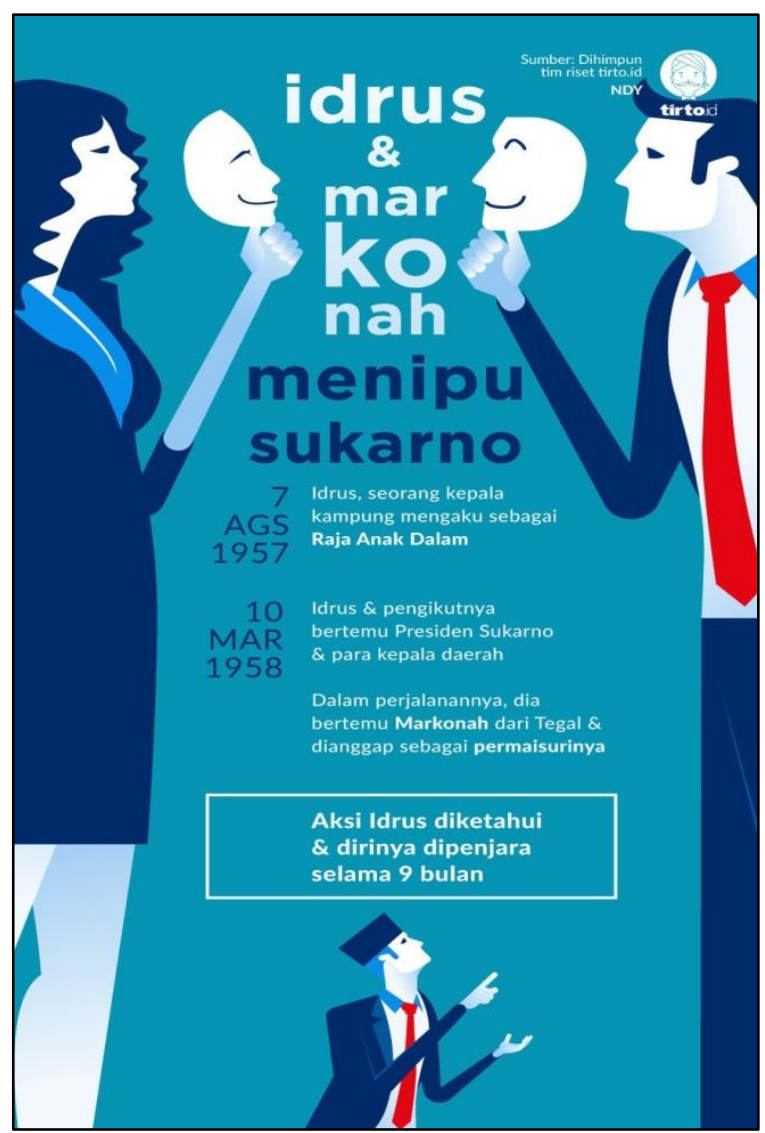

Gambar 4.

Infografis Idrus dan Markonah

(Sumber : Tirto, 2018)

Pada kasus Sunda Empire, para petingginya justru memiliki jeratan hukum yang berbeda. Kasus Sunda Empire tidak berkaitan dengan kasus penipuan melainkan terjerat dengan kasus penyebaran berita bohong (hoax). Ketiga pemimpin Sunda Empire dijerat dengan Pasal 14 dan 15 UU No.1 Tahun 1946 tentang kasus menyiarkan berita atau pemberitahuan bohong atau dengan sengaja menerbitkan keonaran di kalangan rakyat, dengan maksimal hukuman 10 tahun penjara (Huyogo, 2020).

\section{Dampak Sosial yang Ditimbulkan dan Ancaman Hukum yang Diberikan Terhadap Organisasi Kemasyarakatan}

Meningkatnya dampak yang terjadi dengan banyaknya kasus penipuan yang terjadi menjadi fokus tersendiri dalam penegakan hukum. Berdasarkan jurnal yang berjudul Peningkatan Rasio Kejahatan Cyber dengan Pola Interaksi Sosio Engineering pada Periode Akhir Era Society 4.0 di Indonesia (Palinggi, Palelleng, \& Allolinggi, 2020), disebutkan bahwa jumlah laporan perihal penipuan secara online paling mendominasi, yakni sebanyak 1.243 kasus untuk periode Januari 2019 sampai Juli 2019 diantara seluruh laporan kejahatan cyber yang berjumlah 3.130 kasus. Hal ini jelas merupakan sebuah tugas yang tidak mudah dalam memerangi penyebaran kasus penipuan baik secara online maupun dalam kasus face to face.

Dampaknya pun tidak main-main. Kehilangan kepercayaan terhadap pemerintah dan aparat penegakan hukum merupakan hal patut diwaspadai dalam memerangi berbagai kasus kejahatan. Peraturan UU Ormas Tahun 2013 memiliki prosedur penertiban atau pemberian sanksi yang bertahap. Berbeda dengan sanksi yang ditetapkan pada UU Ormas terbaru yang cenderung langsung pada pembubaran organisasi. Undang-Undang No. 17 Tahun 2013 melakukan pemberian sanksi secara ringan hingga sampai pencabutan status hukumnya dengan menerapkan proses demokrasi dan supremasi hukum (Pambudi \& Milla, 2019).

\section{KESIMPULAN}

Dari analisis yang telah diberikan, dapat disimpulkan bahwa potensi penyalahgunaan organisasi kemasyarakatan dapat menimbulkan berbagai macam bentuk kejahatan serius seperti penipuan, dan penyebaran berita bohong. Dalam berbagai kasus, kejahatan yang terorganisir secara teratur dan massif dapat menyebabkan kegaduhan di masyarakat.

Tingkat kepercayaan pengikut dari organisasi fiktif tersebut disebabkan oleh ketidaktahuan masyarakat terkait organisasi tersebut secara lebih mendetail mengenai 
visi dan misi organisasi. Ini merupakan pertanda bahwa masyarakat Indonesia cenderung tergoda dengan romantisme sejarah masa lalu khususnya yang menyangkut organisasi kemasyarakatan berciri kerajaan. Hal ini pula secara tidak langsung mengerus kepercayaan masyarakat terhadap pemerintah dan aparat penegakan hukum dalam melangsungkan roda ketatakenegaraan dalam masyarakat.

Eksistensi dari organisasi kemasyarakatan maupun para pemimpinnya cenderung memiliki motif seperti ketenaran dan bahkan faktor ekonomi. Masyarakat pun diharapkan lebih jeli, selektif dan hati-hati dalam menyeleksi jenis organisasi kemasyarakatan yang ada di lingkungan tempat mereka tinggal agar tidak menjadi objek dari kasus penipuan yang terjadi dengan mengatasnamakan organisasi kemasyarakatan. Selain itu, pemerintah hendaknya terus memantau dengan cara memberikan sanksi tegas bahkan pembubaran organisasi kemasyarakatan tersebut jika terbukti melanggar UU yang berlaku di Indonesia guna melindungi masyarakat dari berbagai kasus kejahatan.

\section{DAFTAR PUSTAKA}

Anugrahadi, A. 2020. HEADLINE: Munculnya Keraton Agung Sejagat, demi Eksistensi atau Penipuan? Retrieved March 24, 2020, from Liputan 6 website: https://www.liputan6.com/news/read/4156 121/headline-munculnya-keraton-agungsejagat-demi-eksistensi-atau-penipuan

Bunga, H., \& Sugiharto, J. 2020. 5 Fakta Sunda Empire: Perang Nuklir Berujung Tersangka. Retrieved April 24, 2020, from Tempo website: https://nasional.tempo.co/read/1300907/5 -fakta-sunda-empire-perang-nuklirberujung-tersangka/full\&view=ok

Bungin, B. 2011. Penelitian Kualitatif: Komunikasi, Ekonomi, Kebijakan Publik, dan IImu Sosial Lainnya. In Kencana. https://doi.org/10.1002/jcc.21776

Dzulfaroh, A. N., \& Nugroho, R. S. 2020. Ramai soal Keraton Agung Sejagat, Mengapa Deklarasi Kerajaan Itu Muncul? Retrieved March 24, 2020, from Kompas website:

https://www.kompas.com/tren/read/2020/ 01/15/054600665/ramai-soal-keratonagung-sejagat-mengapa-deklarasi-

kerajaan-itu-muncul-

Farasonalia, R., \& Arief, T. M. V. 2020. Raja Keraton Agung Sejagat Minta Maaf, Akui Buat Kerajaan Fiktif. Retrieved March 24, 2020, from Kompas website: https://semarang.kompas.com/read/2020/ 01/21/14245361/raja-keraton-agungsejagat-minta-maaf-akui-buat-kerajaanfiktif?page=all

Huyogo. 2020. Tiga Petinggi Sunda Empire Tersangka Kasus Berita Bohong. Retrieved March 24, 2020, from CNN Indonesia website: https://www.cnnindonesia.com/nasional/2 0200128164918-12-469482/tiga-petinggisunda-empire-tersangka-kasus-beritabohong

Klau Lekik, O., Palinggi, S., \& Ranteallo, I. C. 2019. The Descriptive Analysis of Hoax Spread Through Social Media in Indonesia Media Perspective. International Conference on AntiCorruption and Integrity (ICOACI), 27. Retrieved from http://www.icoaci.com

Marwenny, E., Fauzi, E., \& Cenery, J. P. 2018. Kedudukan Organisasi Kemasyarakatan Asing Di Indonesia Di Tinjau Dari Peraturan Pemerintah Nomor 59 Tahun 2016. JCH (Jurnal Cendekia Hukum). Vol 3. No 2.

Matanasi, P. 2018. Cara Idrus dan Markonah Menipu Para Pejabat Republik. Retrieved March 24, 2020, from Tirto website: https://tirto.id/cara-idrus-danmarkonah-menipu-para-pejabat-republikdcuT

Oktavian, S. 2020. Enggan Disamakan Kerajaan Fiktif Lainnya, Raja Kutai Mulawarman Tunjukan SK dari Kemenkumham. Retrieved March 24, 2020, from TribunNewsWiki website: https://www.tribunnewswiki.com/2020/02/ 06/enggan-disamakan-kerajaan-fiktiflainnya-raja-kutai-mulawarman-tunjukansk-dari-kemenkumham?page $=4$

Palinggi, S., Palelleng, S., \& Allolinggi, L. R. 2020. Peningkatan Rasio Kejahatan Cyber Dengan Pola Interaksi Sosio Engineering Pada Periode Akhir Era 
Society 4.0 di Indonesia. Jurnal IImiah Dinamika Sosial (JIDS). Vol 4. No 1. 145163 pp. Retrieved from http://journal.undiknas.ac.id/index.php/fisi p/article/view/2314

Pambudi, Y., \& Milla, M. N. 2019. Potensi Penyalahgunaan Kekuasaan pada Undang-Undang Organisasi Masyarakat Pasal 59 (4) Huruf C. Deviance: Jurnal Krimonologi. Vol 3. No 1. 37-53 pp.

Prabawati, G. 2020. Raja dan Ratu Keraton Agung Sejagat Ditangkap, Terancam Hukuman 10 Tahun Penjara. Retrieved March 24, 2020, from Tribun News website:

https://www.tribunnews.com/regional/202 0/01/15/raja-dan-ratu-keraton-agungsejagat-ditangkap-terancam-hukuman10-tahun-penjara

Rusmana, A. 2015. Penipuan Dalam Interaksi Melalui Media Sosial. Jurnal Kajian Informasi \& Perpustakaan. Vol 3. No 2. 187-194 pp.

Ucu, K. R. 2020. Menguliti Kebohongan Klaim Sunda Empire. Retrieved March 24, 2020, from Republika website: https://republika.co.id/berita/q4to12282/ menguliti-kebohongan-klaim-sundaempire

Wiryono, S., \& Carina, J. 2020. Muncul "Raja" Baru King of The King, Klaim Kuasai Rp 60.000 T dan Akan Lantik Presiden di Dunia. Retrieved March 24, 2020, from Kompas website: https://megapolitan.kompas.com/read/20 20/01/27/22060431/muncul-raja-baruking-of-the-king-klaim-kuasai-rp-60000-tdan-akan-lantik

Zainuddin, D. 2016. Analisis Penanganan Konflik Antar Organisasi Kemasyarakatan Di Sumatera Utara (Medan) Dan Jawa Tengah (Surakarta). Jurnal HAM. Vol 7. https://doi.org/10.30641/ham.2016.7.67 